\title{
Associations between promoter usage and alternative splicing of the glucocorticoid receptor gene
}

\author{
Henk Russcher ${ }^{1}$, Virgil A S H Dalm ${ }^{1}$, Frank H de Jong ${ }^{1}$, Albert O Brinkmann², Leo J Hofland ${ }^{1}$, \\ Steven W J Lamberts ${ }^{1}$ and Jan W Koper ${ }^{1}$ \\ Departments of ${ }^{1}$ Internal Medicine and ${ }^{2}$ Department of Reproduction and Development, Erasmus MC, University Medical Center Dr Molewaterplein 40, PO BOX 2040, 3000 CA, \\ Rotterdam, Rotterdam, The Netherlands \\ (Requests for offprints should be addressed to J W Koper; Email: f.koper@erasmusmc.nl)
}

\begin{abstract}
The glucocorticoid receptor $(G R)$ is widely expressed in various tissues throughout the human body. At least three different $3^{\prime}$-splice variants of the GR have been reported: GR- $\alpha$, which is functionally active; GR- $\beta$, which is a dominant negative inhibitor of GR- $\alpha$ function; and GR-P, which is thought to activate the function of GR- $\alpha$. At least seven different variants for exon 1 exist, $1 \mathrm{~A}-1 \mathrm{~F}$ and $1 \mathrm{H}$, each with its own promoter. In this study, we explored if tissue-specific splicing of the $3^{\prime}$-end variants of the GR is influenced by alternative promoter usage. cDNAs of different tissues and cell lines were used to investigate which part of transcripts carrying each of the three major variants for exons $1,1 \mathrm{~A}, 1 \mathrm{~B}$, or $1 \mathrm{C}$, encodes for the splice variants GR- $\alpha$, GR- $\beta$, and GR-P. Our data demonstrate that the expression of GR- $\alpha$ is preferentially regulated by promoter $1 \mathrm{C}$ and that for the expression of GR-P promoter $1 \mathrm{~B}$ is predominantly used. This indicates that regulation of GR splice variants could partly occur through selective use of the multiple promoters, and that this is another way to sensitize cells and tissues to the different activities of the GR isoforms.
\end{abstract}

Journal of Molecular Endocrinology (2007) 38, 91-98

\section{Introduction}

Glucocorticoids (GCs, cortisol, and its synthetic analogs) can influence gene expression via the glucocorticoid receptor (GR). Unliganded GR resides in the cytoplasm but translocates to the nucleus upon GC binding, where it acts as a factor regulating gene transcription (Buckbinder \& Robinson 2002). The GR-encoding gene (NR3C1) is located on chromosome $5 q 31.3$ and has nine exons (Hollenberg et al. 1985). Transcription of the gene results in a broad range of mRNA transcripts that can differ in their $5^{\prime}$ - and $3^{\prime}$-ends (Fig. 1; Lu \& Cidlowski 2004, Turner \& Muller 2005).

Alternative splicing generates three different $3^{\prime}$-end mRNA transcripts, encoding the GR- $\alpha$, GR- $\beta$, and GR-P isoforms respectively. The GR- $\alpha$ isoform (Fig. 1) consists of 777 amino acids and is the functionally active isoform that mediates GC action. The GR- $\beta$ transcript is generated by linking exons 8 to $9 \beta$ instead of exon $9 \alpha$ (Fig. 1), resulting in a 742 amino acid protein (Hollenberg et al. 1985). This GR- $\beta$ protein is not able to bind ligand and is reported to be a dominantnegative inhibitor of GR- $\alpha$ action (Bamberger et al. 1995, Oakley et al. 1996). GR- $\beta$ is expressed in almost every tissue and in many cell lines, albeit at a very low level (0-2\%) compared with GR- $\alpha$ (Oakley et al. 1996, Pujols et al. 2002). Despite its wide tissue expression pattern, controversy remains about its physiological relevance (Carlstedt-Duke 1999, Vottero \& Chrousos 1999). A third 3 '-end mRNA variant only contains exons 2-7 and continues into intron G. The corresponding truncated GR protein of 676 amino acids (Fig. 1) lacks a large portion of the ligand-binding domain, and is therefore also unable to bind ligand (Krett et al. 1995). GR-P is widely expressed in various tissues and cells, up to $55 \%$ of that of GR- $\alpha$ in several hematological malignancies (de Lange et al. 2001, Hagendorf et al. 2005). The function of GR-P is also still not fully understood, but in contrast to GR- $\beta$ it has been reported to enhance GR- $\alpha$-mediated gene transcription (de Lange et al. 2001).

In contrast to alternative splicing at the $3^{\prime}$-end of the GR mRNA, alternative splicing at the $5^{\prime}$-end does not affect the GR protein structure. The differences are restricted to the $5^{\prime}$-untranslated region (UTR), which is composed of exon 1 and the first 13 nucleotides of exon 2. Initially, three variant exons 1 (1A, 1B, and 1C; Breslin et al. 2001) were described. These alternative exons 1 are each preceded by their own promoter (Fig. 1; Nobukuni et al. 1995, Breslin et al. 2001). Moreover, exon 1A was reported to contain three alternative splice sites, resulting in mRNA transcripts containing exons 1A1, 1A2, or 1A3, which means that at least five GR transcripts could be expressed from three separate promoters (Breslin et al. 2001), possibly resulting in cell-typespecific GR expression patterns. Transcripts containing 


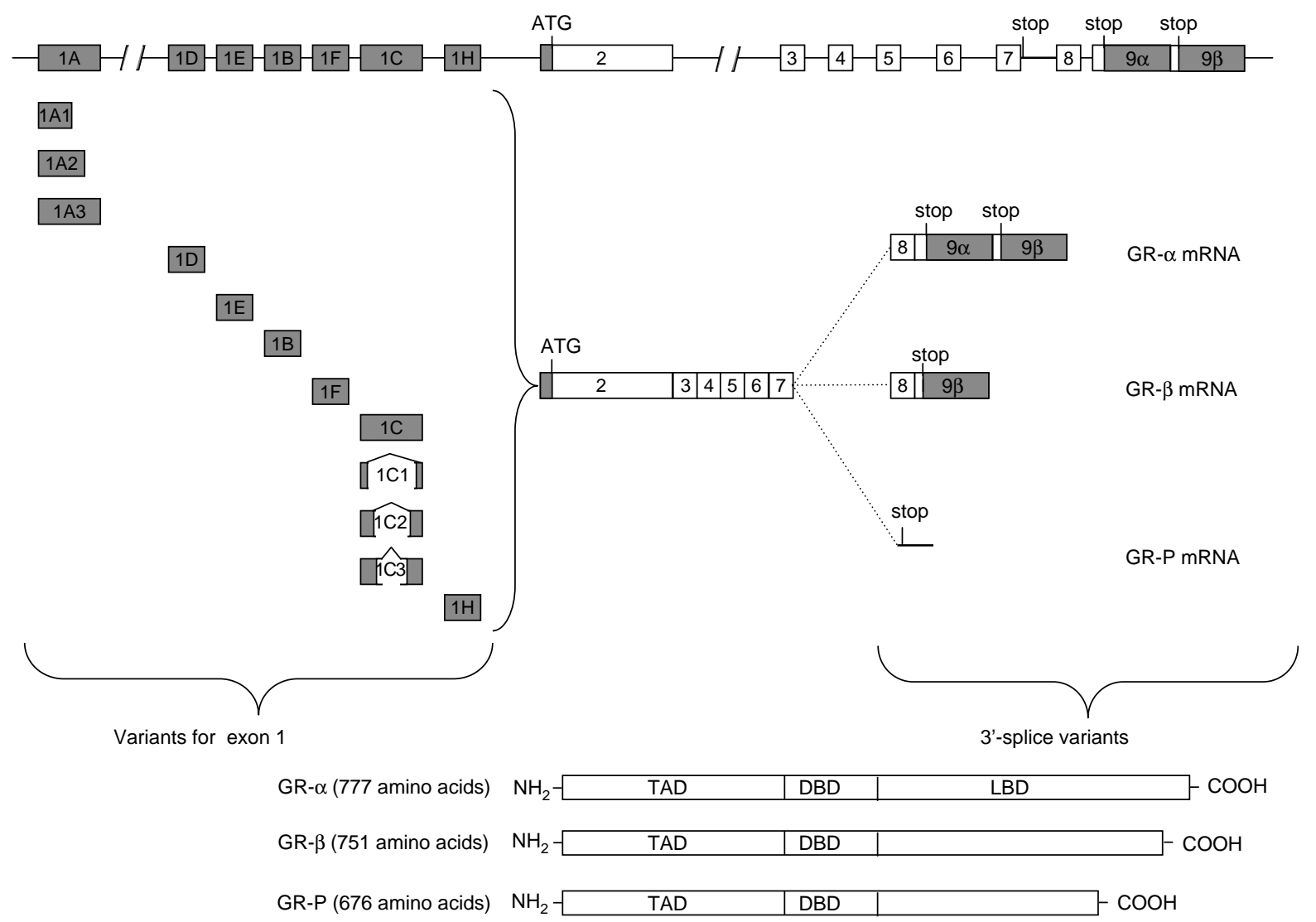

Figure 1 Organization and expression of the GR gene. The expression of the GR gene is controlled by multiple promoters yielding mRNAs containing various exons 1 . mRNAs containing exons $1 \mathrm{~B}$ and $1 \mathrm{C}$ are widely expressed and thought to play a role in the basal tissue-unspecific expression of the GR, while the expression of exons $1 \mathrm{~A}, 1 \mathrm{D}-1 \mathrm{~F}$, and $1 \mathrm{H}$ appears to follow a tissue-specific expression pattern. Exons $1 \mathrm{~A}$ and $1 \mathrm{C}$ are subject to (internal) differential splicing resulting in exons 1A1, 1A2, 1A3, and 1C1, 1C2, $1 \mathrm{C} 3$ respectively. The various $5^{\prime}$-end untranslated exons are spliced to the same splice acceptor site in exon 2 . $3^{\prime}$-End alternative splicing results in mRNAs encoding three variants of the GR gene: GR- $\alpha$, the functionally active protein; GR- $\beta$, a dominant negative inhibitor of GR- $\alpha$ function, unable to bind ligand; and GR-P, a truncated isoform, also unable to bind ligand but thought to increase the activity of GR- $\alpha$.

exons $1 \mathrm{~B}$ and $1 \mathrm{C}$ are ubiquitously expressed and are probably responsible for the basal GR expression (Nunez \& Vedeckis 2002). Transcripts containing 1A1 and $1 \mathrm{~A} 2$ are marginally expressed, even less than GR- $\beta$, while mRNA transcripts containing exon 1A3 are expressed in cells of the hematopoietic lineage (Pedersen \& Vedeckis 2003, Pedersen et al. 2004). Footprint and functional analysis of the promoter regions reveal unique binding sites for several transcription factors, but only promoter $1 \mathrm{~A}$ harbors a sequence resembling a glucocorticoid receptor element (GRE) and could probably be autoregulated by the GR (Pedersen et al. 2004, Purton et al. 2004). In the rat, a more complicated organization of the $5^{\prime}$-part of the $G R$ gene was found (McCormick et al. 2000). Here, at least 11 potential alternatives for exon 1 have been identified that showed a tissue-specific expression pattern. Recently, it was shown (Turner \& Muller 2005) that in the human GR gene five additional exon 1 variants were present, based upon sequence homology between human and rat. The authors could detect expression of four of these five exons (D-F and H), and they also found that exon 1C is subject to (internal) differential splicing (Turner \& Muller 2005; Fig. 1). As in the rat, the expression of these exon 1 variants appears to follow a tissue-specific pattern.

Heterogeneity in the $5^{\prime}$-ends of mRNAs generated by alternative promoter usage seems to be a common feature among the members of the steroid hormone receptor family (Flouriot et al. 1998, Auboeuf et al. 2005). Furthermore, recent studies reported that promoter structure could modulate alternative splicing and suggest a physical and functional coupling between transcription and splicing (Auboeuf et al. 2002, 2004, Kornblihtt 2005). To determine whether splicing of the 3 -end variants of the GR is influenced by alternative promoter usage, 
we explored whether correlations exist between the most abundantly expressed exon 1 variants $(1 \mathrm{~A}, 1 \mathrm{~B}$, and $1 \mathrm{C})$ in the mRNA and $3^{\prime}$-end splicing $(\alpha, \beta$, or $\mathrm{P})$.

\section{Materials and methods}

\section{Cell culture}

Epstein-Barr virus (EBV)-transformed lymphoblast cell lines were established from PBMLs as described previously (Chrousos et al. 1986, Tomita et al. 1986). Cells were grown in Roswell Park Memorial Institute (RPMI)-1640 medium supplemented with $15 \%$ FCS, $100 \mu \mathrm{g} / \mathrm{ml}$ penicillin and streptomycin under standard culture conditions.

\section{cDNA}

cDNAs were prepared as described previously (Dalm et al. 2004). Normal tissue samples were kindly provided by the Erasmus MC Tissue Bank, Rotterdam, The Netherlands. Thymic tissue samples were collected during operations. The tissue samples, taken during postmortem or operation, were directly frozen and stored at $-80^{\circ} \mathrm{C}$ until use. The protocols were in accordance with the Helsinki Doctrine on Human Experimentation. Informed consent was obtained. cDNAs prepared from tissues taken during postmortem or operations were: lung $(n=2)$, ileum $(n=3)$, colon $(n=2)$, rectum $(n=2)$, thyroid $(n=2)$, testes $(n=2)$, adrenal $(n=4)$, kidney $(n=2)$, jejunum $(n=2)$, pancreas $(n=2)$, stomach $(n=1)$ according to protocols as previously described (Dalm et al. 2004). cDNAs prepared from cells of the hematopoietic lineage: $\mathrm{T}$ cells $(n=2)$, B cells $(n=2)$, macrophages $(n=4)$, monocytes $(n=2)$, dendritic cells $(n=2)$, and thymocytes $(n=2)$. cDNAs prepared from several untreated cell lines: B lymphoblasts $(n=2)$, Jurkat $(n=1)$, SaOs-1 $(n=2), \operatorname{Mg} 63-1 \quad(n=2)$, simian virus40 transformed human fetal osteoblast (SV-HFO) $(n=2)$, PancI $(n=1)$, Miapaca $(n=1)$, Bon $(n=1)$, and BxPc3 $(n=1)$. cDNAs prepared from tumor tissue were: liver tumor $(n=1)$, pituitary tumor $(n=1)$, lymph tumor $(n=1)$, pheochromocytoma $(n=1)$, and renal tumor $(n=1)$.

\section{RT-PCR}

To investigate if GR- $\alpha$-, GR- $\beta$-, and GR-P-encoding transcripts are transcribed from all three different promoters, 1A, 1B, and 1C, RT-PCR was performed by using $5^{\prime}$-end (exon 1 specific) and $3^{\prime}$-end (3'-splice variant specific) primer combinations as indicated. These primers were also used for the quantitative realtime RT-PCR experiments and are shown in Table 1. PCR conditions, using the RT-PCR One Step Titan One Tube RT-PCR System (Roche), were as follows. A total of $250 \mathrm{ng}$ RNA was incubated with a reaction mix containing $0 \cdot 4 \mu \mathrm{l}$ enzyme mix, $0 \cdot 2 \mathrm{mM}$ dNTPs, $0 \cdot 25 \mu \mathrm{M}$ forward (FW) primer, $0 \cdot 25 \mu \mathrm{M}$ backward (BW) primer, $5 \mathrm{mM}$ DDT, 1 U Protector RNAse, and water in a total volume of $20 \mu \mathrm{l}$. Cycle conditions were: $30 \mathrm{~min} 50^{\circ} \mathrm{C}$; then 10 cycles: $2 \min 94^{\circ} \mathrm{C}, 10 \mathrm{~s} 94^{\circ} \mathrm{C}, 10 \mathrm{~s} 60^{\circ} \mathrm{C}, 2.5 \mathrm{~min}$ $68^{\circ} \mathrm{C}$; then 25 cycles $10 \mathrm{~s} 94^{\circ} \mathrm{C}, 10 \mathrm{~s} 60^{\circ} \mathrm{C}, 2 \cdot 5 \min 68^{\circ} \mathrm{C}$, with an additional $5 \mathrm{~s}$ extension to the elongation time for each cycle. A PE-Applied Biosystem Gene Amp 9700 PCR-system (Nieuwerkerk aan de IJssel,

Table 1 Primers used for Quantitative real-time RT-PCR analysis

\section{Primer}

GR exon 6 (FW)

GR- $\alpha$ (BW)

Probe

GR exon 6 (FW)

GR- $\beta$ (BW)

Probe

GR exon 6 (FW)

GR-P (BW)

Probe

GR-1A3 (FW)

GR exon 2 (BW)

Probe

GR-1B (FW)

GR exon 2 (BW)

Probe

GR-1C (FW)

GR exon 2 (BW)

Probe

FW, forward; BW, backward.

\author{
5'-TGTTTTGCTCCTGATCTGA-3' \\ 5'-TCGGGGAATTCAATACTCA-3' \\ FAM-TGACTCTACCCTGCATGTACGAC-TAMRA \\ 5'-TGTTTTGCTCCTGATCTGA-3' \\ 5'-TGAGCGCCAAGATTGT-3' \\ FAM-TGACTCTACCCTGCATGTACGAC-TAMRA \\ 5'-TGTTTTGCTCCTGATCTGA-3' \\ 5'-CCTTTGTTTCTAGGCCTTC-3' \\ FAM-TGACTCTACCCTGCATGTACGAC-TAMRA \\ 5'-CCCTCCTCGGGCTTTAGTTGT-3' \\ 5'-GGGTGAAGACGCAGAAACCTT-3' \\ FAM-CCCCAGCAGTGTGCTTGCTCAGGA-TAMRA \\ $5^{\prime}$-CCGGCCCAAATTGATATTC-3' \\ 5'-GGGTGAAGACGCAGAAACCTT-3' \\ FAM-CCCCAGCAGTGTGCTTGCTCAGGA-TAMRA \\ 5'-GGCTCCTCTGCCAGAGTTGA -3' \\ 5'-GGGTGAAGACGCAGAAACCTT-3' \\ FAM-CCCCAGCAGTGTGCTTGCTCAGGA-TAMRA
}

GR- $\alpha$ mRNA

GR- $\beta$ mRNA

GR-P mRNA

GR-1A mRNA

GR-1B mRNA

GR-1C mRNA 
The Netherlands) was used. PCR products were examined on a u.v. light source after electrophoresis on a $0.7 \%$ agarose gel containing ethidium bromide.

\section{Quantification of the mRNA variants of the GR}

Real-time quantitative (qPCR) analysis of mRNA was performed to investigate the amount of transcripts containing exons $1 \mathrm{~A}, 1 \mathrm{~B}$, or $1 \mathrm{C}$ and the amount encoding GR- $\alpha$, GR- $\beta$, or GR-P. The primers and probes used are shown in Table 1. For each splice variant, $2 \cdot 5 \mu \mathrm{l}$ cDNA, corresponding to $50 \mathrm{ng}$ total RNA, were amplified in separate reactions in a total volume of $25 \mu \mathrm{l}$, containing $7 \cdot 5 \mathrm{pmol}$ of each primer and $5 \mathrm{pmol}$ probe using the Universal Master Mix (Applied Biosystems, Nieuwerkerk a/d IJssel, The Netherlands) for PCRs amplifying the 5'-UTR and the qPCR Core-Kit (Eurogentec, Maastricht, The Netherlands) for PCRs amplifying the 3 -splice variants. Correction for assay variability between the separate reactions for which the same cDNA was used was performed by the housekeeping gene hypoxanthine phosphoribosyltransferase (HPRT) as described previously (Russcher et al. 2005), and calculation of the amounts of mRNA was carried out using the comparative threshold cycle method (Livak \& Schmittgen 2001).

\section{Statistical analysis}

Pearson correlation analysis was performed on data shown in Fig. 2 by using Instat software version 2.01 (GraphPad Software, Inc., San Diego, CA, USA). Data points were fitted with regression lines using the leastsquares method. Statistical significance was set at $P<0 \cdot 05$.

\section{Results}

\section{Tissue distribution of GR exons 1A, 1B, and 1C and $3^{\prime}$-end splice variants}

Human cDNAs, reverse transcribed from RNA isolated from different organ tissue biopsy samples and different cells of the hematopoietic lineage, were used to quantify expression levels of exons 1A, 1B, and 1C, and of GR- $\alpha$, GR- $\beta$, and GR-P mRNA. Figure 3 shows that the different exons 1 and the 3 -end splice variants were differentially expressed in these tissues. The major GR mRNA encoded the GR- $\alpha$ isoform. Expression of GR-P was
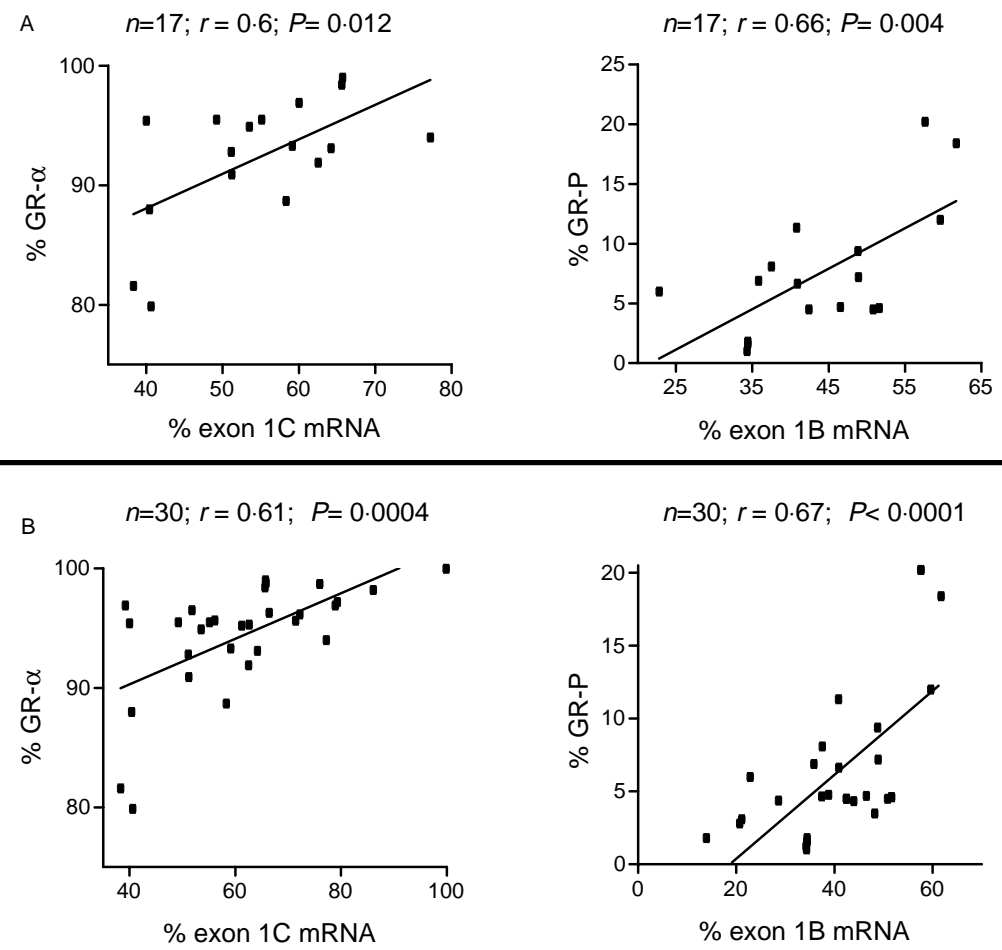

Figure 2 Positive significant correlations between contributions of exons 1 to the total amount of GR mRNA and mRNA encoding $3^{\prime}$-end splice variants. Pearson correlations between the contribution of exon $1 \mathrm{C}$ and GR- $\alpha$ and exon $1 \mathrm{~B}$ and GR-P to the total amount of mRNA expressed in the 17 tissues described in Fig. 3 , and(B) in these 17 tissues combined with 13 additional tissues and cell lines to increase statistical power. 

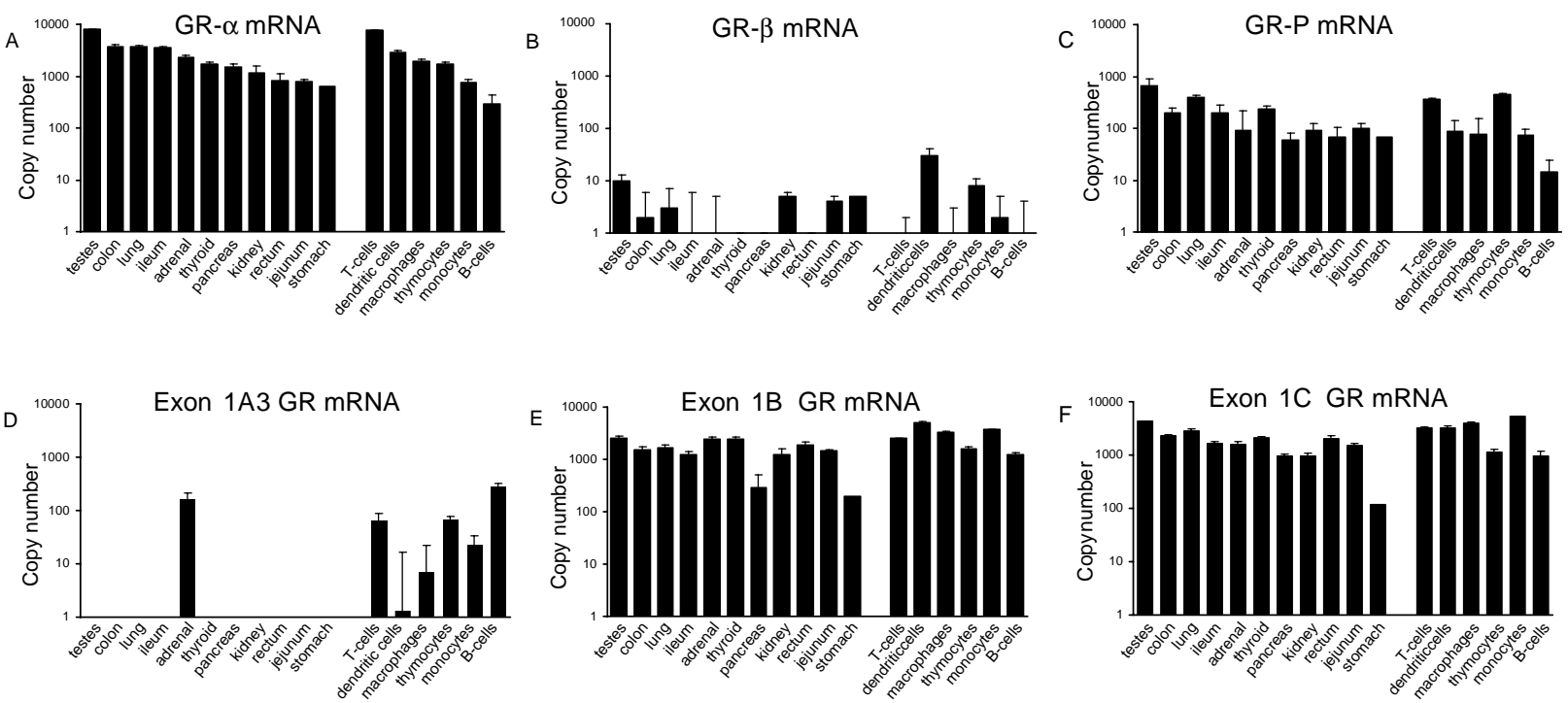

Figure 3 Quantification of mRNA molecules encoding the GR- $\alpha$, GR- $\beta$, GR-P isoforms and carrying exons $1 \mathrm{~A}$, $1 \mathrm{~B}$, or $1 \mathrm{C}$ in different tissues. (A) The number of copies of GR- $\alpha$ mRNA/50 ng total RNA in descending order. (B)-(F) GR- $\beta$, GR-P, exon 1A3, exon 1B, and exon $1 \mathrm{C}$ mRNA expressions respectively, in the same tissues.

about $4-20 \%$ of the expression level of GR- $\alpha$ and GR- $\beta$ mRNA represented $<1 \%$, if at all detectable. Approximately, equal expression levels of exons $1 \mathrm{~B}$ and $1 \mathrm{C}$ were found. mRNA containing exon 1A (1A3) was only detectable in adrenals and in cells of the hematopoietic lineage ( $\mathrm{T}$ cells, B cells, dendritic cells, macrophages, thymocytes, and monocytes). The expression of exons $1 \mathrm{~A} 1$ and $1 \mathrm{~A} 2$ was very low, even less than GR- $\beta$, and it could not be further analyzed. The total amount of different exons 1 and the total amount of $3^{\prime}$-end splice variants are significantly correlated (Pearson $r=0.81$; $P<0 \cdot 001)$, indicating that both represent the amount of total GR present in the different tissues.

\section{Correlation between the different exons $1 \mathrm{~A}, 1 \mathrm{~B}$, and $1 \mathrm{C}$ and the $3^{\prime}$-end splice variants}

Transcripts encoding GR- $\alpha$, GR- $\beta$, and GR-P could theoretically be formed from each of the three different promoters that we investigated: $1 \mathrm{~A}, 1 \mathrm{~B}$, and $1 \mathrm{C}$. Due to the long coding sequence ( $>2000$ nucleotides) between exons 1 and 9, no quantitative real-time RT-PCR could be performed to investigate how the different promoters control expression of these $3^{\prime}$-end splice variants. Therefore, we used semi-quantitative PCR analysis using RNA from a B lymphoblast cell line. Figure 4 shows that GR- $\alpha$ and GR-P mRNA could be expressed from all three promoters $1 \mathrm{~A}, 1 \mathrm{~B}$, and 1C. However, no combinations could be made with the GR$\beta$-specific primer, possibly due to low GR- $\beta$ mRNA levels. Band intensities of the reaction products vary but could be due to varying reaction efficiencies. Different primer combinations were used to amplify the mRNAs and, therefore, further conclusions based on the different signal intensities cannot be drawn. Furthermore, by calculating the percentage of each variant

2500 bp
GR- $\alpha$ mRNA containing exon $1 \mathrm{~A}$
GR- $\beta$ mRNA containing exon $1 \mathrm{~A}$
GR-P mRNA containing exon 1A
GR- $\alpha$ mRNA containing exon $1 \mathrm{~B}$
GR-P mRNA containing exon $1 \mathrm{~B}$
GR- $\alpha$ mRNA containing exon $1 \mathrm{C}$
GR- $\beta$ mRNA containing exon $1 \mathrm{C}$
GR-P mRNA containing exon $1 \mathrm{C}$

Figure 4 Expression of different GR mRNA isoforms in B lymphoblasts. PCR analysis was performed in B lymphoblasts to investigate the expression of the indicated mRNA molecules. The specific amplification of these mRNA molecules was achieved by using the underlined primers shown in Table 1. In these $B$ lymphoblasts, GR- $\alpha$ as well as GR-P expression is driven from promoters $1 \mathrm{~A}, 1 \mathrm{~B}$, and $1 \mathrm{C}$. No amplification of GR- $\beta$ encoding mRNA was detected. 
contributing to the total amount of GR mRNA presented in Fig. 3, correlations were made between the different exon 1 and the 3 '-end splice variants. Positive significant correlations were found between the contributions of exon 1B and the GR-P splice variant (Pearson $r=0 \cdot 66, P=0 \cdot 004$ ) and between exon 1C and the GR- $\alpha$ splice variant (Pearson $r=0 \cdot 6, P=0 \cdot 012$; Fig. 2A). No positive correlations were found between exon $1 \mathrm{~A}$ and the 3 '-end splice variants and between GR$\beta$ mRNA expression and the various exons 1 . The correlations presented in Fig. 2B are based on 17 tissue samples and 13 additional cDNAs, which were obtained from different cell lines and tumor tissues to increase statistical power. These samples were obtained from various other studies and not included in Fig. 3, because cDNA was prepared with non-comparable amounts of RNA. In these additional tissues, similar correlations were found between exons $1 \mathrm{~B}$ and GR-P (Pearson $r=0.67, P<0.0001$ ) and between exons 1C and GR- $\alpha$ (Pearson $r=0 \cdot 61, P=0 \cdot 0004$; Fig. 2B). The proportion of 1B usage strongly influences the GR-P splicing route, whereas the proportion of $1 \mathrm{C}$ usage favors the GR- $\alpha$ splicing route.

\section{Discussion}

In $60 \%$ of the human genes, processing of pre-mRNA by specific splice factors results in multiple mRNAs and, hence, multiple proteins (Auboeuf et al. 2002). The factors that influence the selection of splice sites are not understood very well. However, recent evidence reveals that transcription regulation and alternative splicing can be coupled events (Cramer et al. 1997, 1999). The promoter may affect alternative splicing through recruitment of factors with dual functions in transcription and splicing (i.e. factors that contain functional domains for both processes and hence link them). Studies in which promoter structure was changed led to differences in alternative splicing of the transcript, which could not be explained by differences in promoter strength (Cramer et al. 1997). Furthermore, a decreased processing rate of the RNA polymerase II or internal pauses could favor the inclusion of alternative exons, whereas a highly processive polymerase would favor exclusion of these exons. Elongation speed is regulated by the promoter and depends not only on the composition of the recruited transcription complex (de la Mata et al. 2003, Rosonina $e t$ $a l$. 2003), but also on the secondary structure of the premRNA (Eperon et al. 1988). When multiple promoters are involved in the transcription of a particular gene, occupation by promoter-specific transcription factors might differentially influence the transcription/splicing coupling mechanism, leading to alternative splicing (Nogues et al. 2002, Auboeuf et al. 2004).

The GR mRNA is expressed from multiple promoters. Initially, three exon 1 variants (1A-1C) were described (Breslin et al. 2001), each with its own promoter, and recently four additional exon 1 variants (1D-1F and $1 \mathrm{H}$ ) were discovered, based upon sequence homologies between the rat and the human GR gene (McCormick et al. 2000, Turner \& Muller 2005). Promoter 1A is mainly active in cells of hematopoietic origin and contains binding sites for nuclear factor- $\kappa \mathrm{B}$, interferon regulatory factor, and GR (Breslin et al. 2001). Promoters $1 B$ and $1 C$, however, are thought to play a role in the constitutive expression of GR. Constitutive or 'housekeeping' genes typically lack a TATA or CAAT box, but contain multiple GC regions that are potential sites for ubiquitous transcription factors such as SP-1. Four SP-1-binding sites have been identified in promoter $1 \mathrm{~B}$, whereas five were identified in promoter 1C (Nobukuni et al. 1995, Breslin \& Vedeckis 1998). Yin-Yang 1 (YY-1)-binding sites are identified in promoter $1 \mathrm{~B}$ (three sites) and promoter 1C (one site). YY-1 is a transcription factor that can act

Table 2 The abundance of GR exon 1 transcripts in various databases

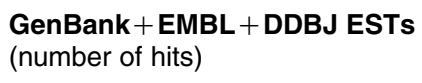

Turner \& Muller (number of positive tissues, total $=15$ )

$\begin{array}{ll}\text { Exon 1 variant } & \\ 1 \mathrm{~A} 1 & 0 \\ 1 \mathrm{~A} 2 & 0 \\ 1 \mathrm{~A} 3 & 15 \text { (partial: } 3^{\prime} \text {-end) } \\ 1 \mathrm{~B} & 30 \\ 1 \mathrm{C} & 30 \\ 1 \mathrm{C} 1 & 0 \\ 1 \mathrm{C} 2 & 0 \\ 1 \mathrm{C} 3 & 0 \\ 1 \mathrm{D} & 0 \\ 1 \mathrm{E} & 0 \\ 1 \mathrm{~F} & 3 \\ 1 \mathrm{H} & 1\end{array}$

n.d., not done. 
as an activator, a repressor, or an initiator of transcription, depending on the cellular context (Shrivastava \& Calame 1994, Nunez \& Vedeckis 2002). AP-1 and AP-2 sites are only identified in promoter 1C (Nunez \& Vedeckis 2002). For the other variants of exon 1, no experimental information is available yet with regard to possible transcription factor binding sites (Turner et al. 2006). Several transcription factors are reported to contain functional domains to recruit splicing factors (Kornblihtt 2005), but whether SP-1, YY-1, AP-1, and AP2 can directly interact with the splicing machinery is unknown.

The recent paper by Turner \& Muller (2005) shows that exons $1 \mathrm{~B}$ and $1 \mathrm{C}$ are the most widely expressed. This is confirmed by a BLAST search of the available human databases of expressed sequence tags (EST; Database of GenBank + EMBL + DDBJ sequences from EST division) and in the Database of Transcription Start Sites (DBTSS, http://dbtss.hgc.jp/, (Kimura et al. 2006)). Both searches yielded mainly entries for 1A, 1B, and 1C (see Table 2). Therefore, in this study, we focused on $1 \mathrm{~A}, 1 \mathrm{~B}$, and $1 \mathrm{C}$. We measured $1 \mathrm{~A}, 1 \mathrm{~B}$, and $1 \mathrm{C}$, but also GR- $\alpha$, GR- $\beta$, and GR-P containing transcripts by quantitative real-time RT-PCR and found associations between promoter usage and alternative splicing of the $G R$ gene. The proportion of 1B usage strongly influences the GR-P splicing route, whereas the proportion of $1 \mathrm{C}$ usage favors the GR- $\alpha$ splicing route (Fig. 2). It should be mentioned that our choice of primers for qPCR of exon $1 \mathrm{C}$ would detect 1C1, 1C2, and 1C3, similar to the 1C-total mentioned in Turner \& Muller (2005), and from these data we cannot determine which of these exon $1 \mathrm{C}$ variants is actually present. However, a semi-quantitative PCR experiment in which $5^{\prime}$-specific primers for the different exons 1 was combined with specific primers for the $3^{\prime}$-splice variants showed that this is not an absolute effect, because PCRs with the possible primer combinations all resulted in amplification products (Fig. 4). Furthermore, associations were found neither with transcripts including exon $9 \beta$, nor with those transcribed from promoter $1 \mathrm{~A}$, but this might be due to the low number of transcripts with these characteristics. Alternatively, GR- $\beta$ splicing might be associated with one of the variants for exon 1 that we did not investigate here $(1 \mathrm{D}-1 \mathrm{~F}$ and $1 \mathrm{H})$. However, in view of the similarity of the total amount of GR mRNA, whether estimated from the exon 1-specific qPCR or from the $3^{\prime}$-end-specific qPCR, suggests that the amount of GR- $\beta$ mRNA incorporating one of these alternatives for exon 1 cannot be very large. The differences in amount of SP-1 and YY-1 transcription factor binding sites in promoters $1 \mathrm{~B}$ and $1 \mathrm{C}$, the presence of AP-1 and AP-2-binding sites in promoter $1 \mathrm{C}$, or the abundance of transcription and splicing factors in the different tissues that are studied might result in a different composition of transcription complexes that are recruited on these promoters, and through associations with splicing factors, influence the ratio in which GR- $\alpha$ and GR-P mRNA is expressed.

The cell-type-specific use of different promoters in the $G R$ gene, but also the different start sites and exons 1 resulting in differences in secondary structure of the pre-mRNAs might alter the elongation speed at which mRNAs are formed. This could also influence splicing regulation. These $5^{\prime}$ differences are restricted to the non-coding region and do not influence the open reading frame, which starts in exon 2 . If alternative promoter usage and splice site selection for GR expression are linked through either transcription factor recruitment or elongation speed by means of such a coupling remains to be proven. Any supporting evidence should first rule out the possibility that alternative splice variants are the consequence of important changes in pre-mRNA secondary structure resulting from the different exon 1 sequences.

Nonetheless, our data demonstrate that GR- $\alpha$ expression is related to the use of $1 \mathrm{C}$ promoter and that expression of GR-P is related to the use of $1 \mathrm{~B}$ promoter. The regulation of GR splice variants through the multiple promoters and the cell-type-specific expression of transcription factors is another way in which cells and tissues can be sensitized to the actions of GCs and the functions of the different splice variants.

\section{Acknowledgements}

This work was supported by the Netherlands Organization for Scientific Research (NWO) under Grant 90343-092 and Grant 903-43-093. The authors declare that there is no conflict of interest that would prejudice the impartiality of this scientific work.

\section{References}

Auboeuf D, Honig A, Berget SM \& O’Malley BW 2002 Coordinate regulation of transcription and splicing by steroid receptor coregulators. Science 298 416-419.

Auboeuf D, Dowhan DH, Kang YK, Larkin K, Lee JW, Berget SM \& O'Malley BW 2004 Differential recruitment of nuclear receptor coactivators may determine alternative RNA splice site choice in target genes. PNAS 101 2270-2274.

Auboeuf D, Dowhan DH, Dutertre M, Martin N, Berget SM \& O'Malley BW 2005 A subset of nuclear receptor coregulators act as coupling proteins during synthesis and maturation of RNA transcripts. Molecular and Cellular Biology 25 5307-5316.

Bamberger CM, Bamberger AM, de Castro M \& Chrousos GP 1995 Glucocorticoid receptor beta, a potential endogenous inhibitor of glucocorticoid action in humans. Journal of Clinical Investigations 95 2435-2441.

Journal of Molecular Endocrinology (2007) 38, 91-98 
Breslin MB \& Vedeckis WV 1998 The human glucocorticoid receptor promoter upstream sequences contain binding sites for the ubiquitous transcription factor, Yin Yang 1. Journal of Steroid Biochemistry and Molecular Biology 67 369-381.

Breslin MB, Geng CD \& Vedeckis WV 2001 Multiple promoters exist in the human GR gene, one of which is activated by glucocorticoids. Molecular Endocrinology 15 1381-1395.

Buckbinder L \& Robinson RP 2002 The glucocorticoid receptor: molecular mechanism and new therapeutic opportunities. Current Drug Targets. Inflammation and Allergy 1 127-136.

Carlstedt-Duke J 1999 Glucocorticoid receptor beta: view II. Trends in Endocrinology and Metabolism 10 339-342.

Chrousos GP, Loriaux DL, Tomita M, Brandon DD, Renquist D, Albertson B \& Lipsett MB 1986 The new world primates as animal models of glucocorticoid resistance. Advances in Experimental Medicine and Biology 196 129-144.

Cramer P, Pesce CG, Baralle FE \& Kornblihtt AR 1997 Functional association between promoter structure and transcript alternative splicing. PNAS 94 11456-11460.

Cramer P, Caceres JF, Cazalla D, Kadener S, Muro AF, Baralle FE \& Kornblihtt AR 1999 Coupling of transcription with alternative splicing: RNA pol II promoters modulate SF2/ASF and 9G8 effects on an exonic splicing enhancer. Molecular Cell 4 251-258.

Dalm VA, Van Hagen PM, de Krijger RR, Kros JM, Van Koetsveld PM, Van Der Lely AJ, Lamberts SW \& Hofland LJ 2004 Distribution pattern of somatostatin and cortistatin mRNA in human central and peripheral tissues. Clinical Endocrinology (Oxf) 60 625-629.

Eperon LP, Graham IR, Griffiths AD \& Eperon IC 1988 Effects of RNA secondary structure on alternative splicing of pre-mRNA: is folding limited to a region behind the transcribing RNA polymerase? Cell $\mathbf{5 4}$ 393-401.

Flouriot G, Griffin C, Kenealy M, Sonntag-Buck V \& Gannon F 1998 Differentially expressed messenger RNA isoforms of the human estrogen receptor-alpha gene are generated by alternative splicing and promoter usage. Molecular Endocrinology 12 1939-1954.

Hagendorf A, Koper JW, de Jong FH, Brinkmann AO, Lamberts SW \& Feelders RA 2005 Expression of the human glucocorticoid receptor splice variants alpha, beta, and $\mathrm{P}$ in peripheral blood mononuclear leukocytes in healthy controls and in patients with hyper- and hypocortisolism. Journal of Clinical Endocrinology and Metabolism 90 6237-6243.

Hollenberg SM, Weinberger C, Ong ES, Cerelli G, Oro A, Lebo R, Thompson EB, Rosenfeld MG \& Evans RM 1985 Primary structure and expression of a functional human glucocorticoid receptor cDNA. Nature 318 635-641.

Kimura K, Wakamatsu A, Suzuki Y, Ota T, Nishikawa T, Yamashita R, Yamamoto J, Sekine M, Tsuritani K, Wakaguri H et al. 2006 Diversification of transcriptional modulation: large-scale identification and characterization of putative alternative promoters of human genes. Genome Research 16 55-65.

Kornblihtt AR 2005 Promoter usage and alternative splicing. Current Opinion in Cellular Biology 17 262-268.

Krett NL, Pillay S, Moalli PA, Greipp PR \& Rosen ST 1995 A variant glucocorticoid receptor messenger RNA is expressed in multiple myeloma patients. Cancer Research 55 2727-2729.

de Lange P, Segeren CM, Koper JW, Wiemer E, Sonneveld P, Brinkmann AO, White A, Brogan IJ, de Jong FH \& Lamberts SW 2001 Expression in hematological malignancies of a glucocorticoid receptor splice variant that augments glucocorticoid receptormediated effects in transfected cells. Cancer Research 61 3937-3941.

Livak KJ \& Schmittgen TD 2001 Analysis of relative gene expression data using real-time quantitative PCR and the 2(-Delta Delta C(T)) method. Methods 25 402-408.

Lu NZ \& Cidlowski JA 2004 The origin and functions of multiple human glucocorticoid receptor isoforms. Annuals of the New York Academy of Sciences 1024 102-123. de la Mata M, Alonso CR, Kadener S, Fededa JP, Blaustein M, Pelisch F, Cramer P, Bentley D \& Kornblihtt AR 2003 A slow RNA polymerase II affects alternative splicing in vivo. Molecular Cell 12 525-532.

McCormick JA, Lyons V, Jacobson MD, Noble J, Diorio J, Nyirenda M, Weaver S, Ester W, Yau JL, Meaney MJ et al. $20005^{\prime}$-Heterogeneity of glucocorticoid receptor messenger RNA is tissue specific: differential regulation of variant transcripts by early-life events. Molecular Endocrinology 14 506-517.

Nobukuni Y, Smith CL, Hager GL \& Detera-Wadleigh SD 1995 Characterization of the human glucocorticoid receptor promoter. Biochemistry 34 8207-8214.

Nogues G, Kadener S, Cramer P, Bentley D \& Kornblihtt AR 2002 Transcriptional activators differ in their abilities to control alternative splicing. Journal of Biological Chemistry 277 43110-43114.

Nunez BS \& Vedeckis WV 2002 Characterization of promoter 1B in the human glucocorticoid receptor gene. Molecular and Cellular Endocrinology 189 191-199.

Oakley RH, Sar M \& Cidlowski JA 1996 The human glucocorticoid receptor beta isoform. Expression, biochemical properties, and putative function. Journal of Biological Chemistry 271 9550-9559.

Pedersen KB \& Vedeckis WV 2003 Quantification and glucocorticoid regulation of glucocorticoid receptor transcripts in two human leukemic cell lines. Biochemistry 42 10978-10990.

Pedersen KB, Geng CD \& Vedeckis WV 2004 Three mechanisms are involved in glucocorticoid receptor autoregulation in a human T-lymphoblast cell line. Biochemistry 43 10851-10858.

Pujols L, Mullol J, Roca-Ferrer J, Torrego A, Xaubet A, Cidlowski JA \& Picado C 2002 Expression of glucocorticoid receptor alpha- and beta-isoforms in human cells and tissues. American Journal of Physiology. Cell Physiology 283 C1324-C1331.

Purton JF, Monk JA, Liddicoat DR, Kyparissoudis K, Sakkal S, Richardson SJ, Godfrey DI \& Cole TJ 2004 Expression of the glucocorticoid receptor from the 1A promoter correlates with $\mathrm{T}$ lymphocyte sensitivity to glucocorticoid-induced cell death. Journal of Immunology 173 3816-3824.

Rosonina E, Bakowski MA, McCracken S \& Blencowe BJ 2003 Transcriptional activators control splicing and 3 '-end cleavage levels. Journal of Biological Chemistry 278 43034-43040.

Russcher H, Smit P, van den Akker EL, van Rossum EF, Brinkmann AO, de Jong FH, Lamberts SW \& Koper JW 2005 Two polymorphisms in the glucocorticoid receptor gene directly affect glucocorticoidregulated gene expression. Journal of Clinical Endocrinology and Metabolism 90 5804-5810.

Shrivastava A \& Calame K 1994 An analysis of genes regulated by the multi-functional transcriptional regulator Yin Yang-1. Nucleic Acids Research 22 5151-5155.

Tomita M, Brandon DD, Chrousos GP, Vingerhoeds AC, Foster CM, Fowler D, Loriaux DL \& Lipsett MB 1986 Glucocorticoid receptors in Epstein-Barr virus-transformed lymphocytes from patients with glucocorticoid resistance and a glucocorticoid-resistant New World primate species. Journal of Clinical Endocrinology and Metabolism 62 $1145-1154$.

Turner JD \& Muller CP 2005 Structure of the glucocorticoid receptor (NR3C1) gene $5^{\prime}$ untranslated region: identification, and tissue distribution of multiple new human exon 1. Journal of Molecular Endocrinology 35 283-292.

Turner JD, Schote AB, Macedo JA, Pelascini LP \& Muller CP 2006 Tissue specific glucocorticoid receptor expression, a role for alternative first exon usage? Biochemical Pharmacology 72 1529-1537.

Vottero A \& Chrousos GP 1999 Glucocorticoid receptor beta: view I. Trends in Endocrinology and Metabolism 10 333-338.

Received in final form 18 October 2006 Accepted 26 October 2006 